\title{
Andrographolide Inhibits Proliferation and Metastasis of SGC7901 Gastric Cancer Cells
}

\author{
Lei Dai, ${ }^{1,2}$ Gang Wang, ${ }^{1,3}$ and Wensheng Pan $^{2}$ \\ ${ }^{1}$ Department of Gastroenterology, Tongde Hospital of Zhejiang Province, Hangzhou, Zhejiang, China \\ ${ }^{2}$ Department of Gastroenterology, The Second Affiliated Hospital, Zhejiang University, School of Medicine, Hangzhou, Zhejiang, China \\ ${ }^{3}$ Tumor Institute of Integrative Medicine, Zhejiang Provincial Academy of Traditional Chinese Medicine, \\ Tongde Hospital of Zhejiang Province, Hangzhou, Zhejiang, China
}

Correspondence should be addressed to Wensheng Pan; wspan223@163.com

Received 9 September 2016; Revised 12 November 2016; Accepted 13 December 2016; Published 18 January 2017

Academic Editor: Hushan Yang

Copyright ( 2017 Lei Dai et al. This is an open access article distributed under the Creative Commons Attribution License, which permits unrestricted use, distribution, and reproduction in any medium, provided the original work is properly cited.

\begin{abstract}
To explore the mechanisms by which andrographolide inhibits gastric cancer cell proliferation and metastasis, we employed the gastric cell line SGC7901 to investigate the anticancer effects of andrographolide. The cell survival ratio, cell migration and invasion, cell cycle, apoptosis, and matrix metalloproteinase activity were assessed. Moreover, western blotting and real-time PCR were used to examine the protein expression levels and the mRNA expression levels, respectively. The survival ratio of cells decreased with an increasing concentration of andrographolide in a dose-dependent manner. Consistent results were also obtained using an apoptosis assay, as detected by flow cytometry. The cell cycle was blocked at the G2/M2 phase by andrographolide treatment, and the proportion of cells arrested at G1/M was enhanced as the dose increased. Similarly, wound healing and Transwell assays showed reduced migration and invasion of the gastric cancer cells at various concentrations of andrographolide. Andrographolide can inhibit cell proliferation, invasion, and migration, block the cell cycle, and promote apoptosis in SGC7901 cells. The mechanisms may include upregulated expression of Timp-1/2, cyclin B1, p-Cdc2, Bax, and Bik and downregulated expression of MMP-2/9 and antiapoptosis protein Bcl-2.
\end{abstract}

\section{Introduction}

Gastric cancer (GC) is one of the most prevalent malignancies. Nearly 1 million new diagnoses and approximately 0.74 million deaths occur worldwide [1]. Indeed, GC is the third most common cancer after lung cancer and liver cancer (breast cancer for women) in China [2-4], with 0.3 million new diagnoses and 0.4 new deaths from GC [4], accounting for $40 \%$ of GC patients globally [3].

Although surgery is still the first choice for GC, most GC patients are at advanced stages upon the initial diagnosis. Furthermore, patients with advanced GC commonly have distant metastasis or/and local invasion, and $50 \%$ of relapsed patients exhibit local lymph node metastasis [3]. Thus, chemo- and radiotherapy (or other means) are the preferred approach for treating advanced GC; common drugs include oxaliplatin, 5$\mathrm{FU}$, and semustine [4]. Although an increasing number of new drugs are being developed and launched, the prognosis is dismal, with a 5 -year survival rate of only $23-36 \%$ [5]. Thus, more effective new drugs are urgently needed. Recently, some naturally derived drugs have shown attractive properties, including andrographolide [6].

Andrographolide (ANDR) is a diterpene lactone that is one of the major components of Andrographis paniculata Nees, a member of the Acanthaceae family and a commonly used Traditional Chinese Medicine with attributes of clearing away heat and toxic materials, cooling the blood, and reducing swelling [7]. The molecular formula of ANDR is $\mathrm{C}_{20} \mathrm{H}_{30} \mathrm{O}$ [8]. Several clinical drugs directed at anti-inflammation, anti-infection, immune system regulation, anticardiovascular disease, and anticancer effects have been developed based on ANDR [9-12].

In the present work, we explored the antiproliferation and antimetastatic functions of ANDR and the potential molecular mechanisms involved. 


\section{Materials and Methods}

2.1. Cell Culture. The GC cell line SGC7901 was purchased from the Shanghai cell bank of the Chinese Academy of Sciences. The cells were cultured in RPMI 1640 medium (HyClone, China) with 10\% fetal bovine serum (FBS) (HyClone, China) in a humidified chamber with $5 \% \mathrm{CO}_{2}$ at $37^{\circ} \mathrm{C}$.

2.2. Reagents and Kits. A $20 \mathrm{mg}$ sample of ANDR (Sigma, USA) was dissolved in $2 \mathrm{ml}$ DMSO (Sigma, USA) to produce a $10 \mathrm{mg} / \mathrm{ml}$ solution. MTT (Sigma, USA), Matrigel (BD, USA), a SYBR Premix ExTaq (Perfect Real Time) kit (TAKARA, China), a cell cycle kit (BD, USA), and an apoptosis kit (BD, USA) were used in this study.

2.3. MTT Assay. Cultured cells were trypsinized for the preparation of single-cell suspensions, which were then seeded in 96-well plates at 5000 cells/well. After $12 \mathrm{~h}$, media was replaced with fresh media containing DMSO (DMSO group) or ANDR (ANDR groups). For each group, 3 wells were run in parallel. All media were incubated for $12 \mathrm{~h}$, $24 \mathrm{~h}, 48 \mathrm{~h}$, and $72 \mathrm{~h}$ before the MTT solution was added, followed by $4 \mathrm{~h}$ of incubation at $37^{\circ} \mathrm{C}$. The supernatant was discarded and $150 \mu \mathrm{l}$ DMSO was added. After $10 \mathrm{~min}$ of shaking, absorption was measured at $490 \mathrm{~nm}$ using a microplate reader.

2.4. Flow Cytometry for Cell Cycle and Apoptosis Analyses. Cells treated under different conditions for $48 \mathrm{~h}$ were detached from 6-well culture plates, washed once with icecold PBS, and pelleted by centrifugation. The cells were then suspended in $75 \%$ ethanol and incubated on ice for $10 \mathrm{~min}$. The cells were centrifuged at $2500 \mathrm{rpm}$ for $5 \mathrm{~min}$ and washed twice with ice-cold PBS. The cell pellets were resuspended in buffer containing PI (Propidium Iodide) and RNase for $15 \mathrm{~min}$ in the dark at $37^{\circ} \mathrm{C}$, and the cell cycle was examined by flow cytometry after filtration.

For apoptosis, both adherent and suspended cultured cells were harvested. After centrifugation at $2500 \mathrm{rpm}$ for $5 \mathrm{~min}$, the cell pellets were resuspended in binding buffer with FITC-labelled Annexin-V and PI dye and incubated for 20 min on ice. Apoptosis was detected by flow cytometry using a BD Canto II (BD, USA).

2.5. Wound Healing Assay. Cells cultured in 6-well plates were scratched with a pipet tip and then washed once with medium. The cells were examined by microscopy at $0 \mathrm{~h}$ and $24 \mathrm{~h}$ after scratching.

2.6. Transwell Assay. Matrigel was diluted with PBS for a final concentration of $50 \mathrm{mg} / \mathrm{l}$, added to the bottom of a transwell, and incubated overnight at $4^{\circ} \mathrm{C}$. After discarding the medium, $10^{5}$ cells were plated into the upper chamber of the transwell (Coring, USA) and cultured with medium containing 2\% FBS; medium containing 20\% FBS was added to the lower well. After $48 \mathrm{~h}$ or $72 \mathrm{~h}$, the cells were fixed with methanol and stained with $0.1 \%$ crystal violet. Microscopy (Olympus, Japan) was used to image the attached cells [13].
2.7. Western Blotting. Cells in 6-well plates were washed twice with PBS and the supernatant was removed. Cell lysis buffer (50 mmol/l Tris at $\mathrm{pH} 7.4,50 \mathrm{mmol} / \mathrm{l} \mathrm{NaCl}, 0.1 \%$ Triton X$100,0.1 \% \mathrm{SDS}, 0.3 \mathrm{mmol} / \mathrm{l}$ sodium orthovanadate, $50 \mathrm{mmol} / \mathrm{l}$ $\mathrm{NaF}, 1 \mathrm{mmol} / \mathrm{l}$ dithiothreitol, $10 \mu \mathrm{g} / \mathrm{ml}$ leupeptin, and $5 \mu \mathrm{g} / \mathrm{ml}$ aprotinin) [14], RIPA, and the proteinase inhibitor, PMSF, were added to wells. The cells were incubated for $15 \mathrm{~min}$ at $4^{\circ} \mathrm{C}$ or on ice. The cell lysate was centrifuged at $12000 \mathrm{rpm}$ at $4^{\circ} \mathrm{C}$. The protein concentration of the supernatant was determined using the BCA kit (Beyotime, China). The supernatant was combined with protein loading buffer and denatured at $100^{\circ} \mathrm{C}$ for $10 \mathrm{~min}$. SDS-PAGE was performed, and the separated proteins were transferred onto membranes (Millipore, USA). The membranes were incubated with antibodies (Abcam, USA). The ZE-ECL kit (Millipore, USA) was used to visualize the protein bands, and a Bio-Rad instrument (Quantity One) was used for imaging.

2.8. Gelatin Zymography. Gel zymography was carried out as previously described [15]. The protein supernatant obtained above was denatured in loading buffer and loaded onto an SDS-PAGE gel containing $1 \%$ gelatin. After electrophoresis, the gels were soaked in washing buffer $(500 \mathrm{ml} 2.5 \%$ Triton X$100,12.5 \mathrm{ml} 50 \mathrm{~mol} / \mathrm{l}$ Tris- $\mathrm{HCl}(1.5 \mathrm{M}), 16.7 \mathrm{ml} 5 \mathrm{~mol} / \mathrm{l} \mathrm{CaCl}_{2}$, and $2.5 \mathrm{~mL} 1 \mu \mathrm{mol} / 1 \mathrm{ZnCl}_{2}$ ) for $15 \mathrm{~min}$, repeated 4 times. The gels were transferred and washed twice with washing buffer ( $50 \mathrm{~mol} / \mathrm{l}$ Tris- $\mathrm{HCl}, 5 \mathrm{~mol} / \mathrm{l} \mathrm{CaCl}_{2}$, and $1 \mu \mathrm{mol} / \mathrm{l} \mathrm{ZnCl}$ ), followed by incubation in buffer $(50 \mathrm{~mol} / \mathrm{l}$ Tris- $\mathrm{HCl}, 5 \mathrm{~mol} / \mathrm{l}$ $\mathrm{CaCl}_{2}, 1 \mu \mathrm{mol} / 1 \mathrm{ZnCl}_{2}$, and $0.02 \% \mathrm{NaN}_{3}$ ) for $48 \mathrm{~h}$ at $37^{\circ} \mathrm{C}$. After the staining and destaining steps, the two apparent bands were scanned using a digital scanner [15].

2.9. Real-Time PCR. Total RNA was extracted from cells in 6well plates using Trizol reagent (Invitrogen, USA) following the manufacturer's recommendations. Complementary DNA was obtained from the RNA using the PrimeScript RT reagent kit (TaKaRa, Dalian), and real-time PCR was performed using a StepOnePlus instrument (ABI, USA) with the SYBR Premix ExTaqII kit (TaKaRa, China). The reaction was cycled at $95^{\circ} \mathrm{C}$ for $5 \mathrm{~min}$, followed by 40 cycles of $95^{\circ} \mathrm{C}$ for $5 \mathrm{~s}$, and $60^{\circ} \mathrm{C}$ for $34 \mathrm{~s}$; the melting curve was obtained from $62^{\circ} \mathrm{C}$ to $95^{\circ} \mathrm{C}$. The primers used for real-time PCR are listed in Table 1.

2.10. Statistics. All data were statistically analyzed using SPSS19.0 software. Numerical data are displayed as the mean $\pm \mathrm{SD}$, and one-way ANOVA or Student's $t$-test was used to compare differences between different groups. A $P$ value of $<0.05$ was regarded as statistically significant.

\section{Results}

3.1. ANDR Inhibited SGC7901 Cell Proliferation. ANDR inhibited SGC7901 cell proliferation at concentrations ranging from 5 to $40 \mu \mathrm{g} / \mathrm{ml}$, in a time- and dose-dependent manner (Figure 1(a), $P<0.01$ ). With this observation, we chose $40 \mu \mathrm{g} / \mathrm{ml}, 20 \mu \mathrm{g} / \mathrm{ml}$, and $5 \mu \mathrm{g} / \mathrm{ml}$ as high $(\mathrm{H})$, moderate (M), and low (L) doses of ANDR in this experiment, respectively. The three doses all significantly decreased the ratio of proliferative cells of SGC7901 cell induced by ANDR 


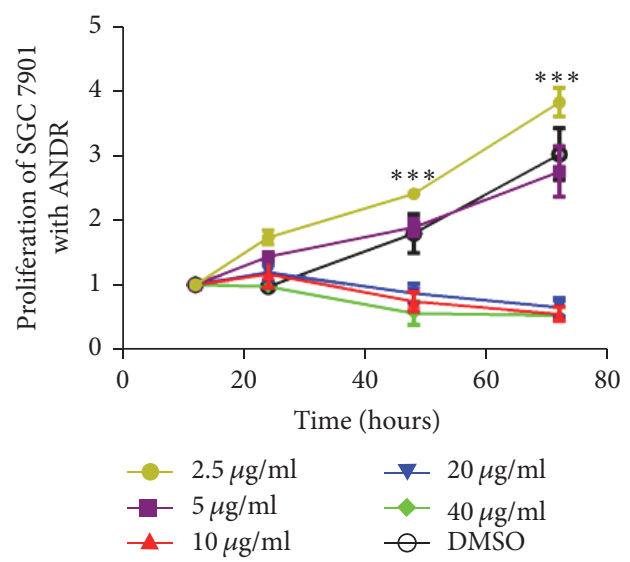

(a)

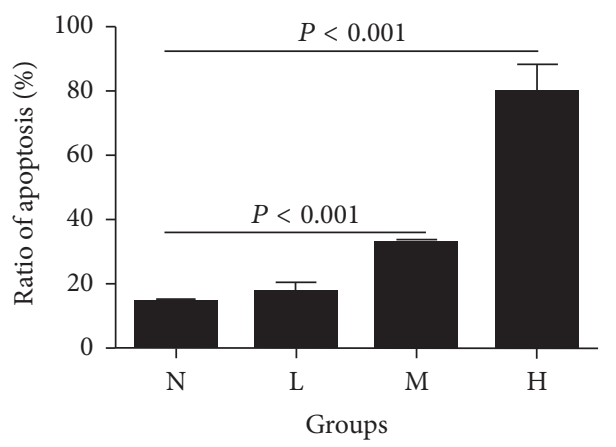

(b)

FIGURE 1: ANDR inhibited proliferation and induced apoptosis in SGC 7901 cells. (a) ANDR at different concentrations inhibited proliferation of SGC 7901 cells. ANDR-treated groups at $40 \mu \mathrm{g} / \mathrm{ml}, 20 \mu \mathrm{g} / \mathrm{ml}$, and $10 \mu \mathrm{g} / \mathrm{ml}$ had a higher capacity of inhibition on the proliferation of gastric cancer cells than the DMSO-treated groups (control) at $5 \mu \mathrm{g} / \mathrm{ml}$ and $2.5 \mu \mathrm{g} / \mathrm{ml}(P<0.001)$. There were no significant differences among the DMSO group treated at $2.5 \mu \mathrm{g} / \mathrm{ml}$ and $5 \mu \mathrm{g} / \mathrm{ml}$. (b) High dosage (H), middle dosage (M), and low dosage (L) ANDR treatment induced apoptosis of SGC 7901 cells. The ratio of apoptotic cells in H group was higher than that of other groups $(P<0.001)$. The ratio of apoptotic cells in $\mathrm{M}$ group was higher than $\mathrm{L}$ and $\mathrm{N}$ (control) groups $(P<0.001)$. There was no significant difference between $\mathrm{N}$ group and L group. ${ }^{* * *}$ After $48 \mathrm{~h}$, the proliferation of groups at $10 \mu \mathrm{g} / \mathrm{mL}, 20 \mu \mathrm{g} / \mathrm{mL}$, and $40 \mu \mathrm{g} / \mathrm{mL}$ of ANDR was inhibited significantly compared to control group (DMSO group) and groups of $2.5 \mu \mathrm{g} / \mathrm{mL}$ and $5 \mu \mathrm{g} / \mathrm{mL}$ of ANDR.

TABLE 1: Primers sequences used in real-time PCR.

\begin{tabular}{lcc}
\hline \multicolumn{2}{c}{ Gene } & Sequence \\
\hline \multirow{2}{*}{ MMP2 } & MMP2-F & TACAGGATCATTGGCTACACACC \\
& MMP2-R & GGTCACATCGCTCCAGACT \\
MMP9 & MMP9-F & GGGACGCAGACATCGTCATC \\
& MMP9-R & TCGTCATCGTCGAAATGGGC \\
BAX & BAX-F & GATGCGTCCACCAAGAAGCT \\
& BAX-R & CGGCCCCAGTTGAAGTTG \\
Bcl-2 & BCL2-F & TCCGCATCAGGAAGGCTAGA \\
& BCL2-R & AGGACCAGGCCTCCAAGCT \\
TIMP1 & TIMP1-F & AGAGTGTCTGCGGATACTTCC \\
& TIMP1-R & CCAACAGTGTAGGTCTTGGTG \\
TIMP2 & TIMP2-F & AAGCGGTCAGTGAGAAGGAAG \\
& TIMP2-R & GGGGCCGTGTAGATAAACTCTAT \\
BIK & BIK-F & CTTGATGGAGACCCTCCTGTATG \\
& BIK-R & AGGGTCCAGGTCCTCTTCAGA \\
Survivin & Survivin-F & AGGACCACCGCATCTCTACAT \\
& Survivin-R & AAGTCTGGCTCGTTCTCAGTG \\
CD147 & CD147-R & GAAGTCGTCAGAACACATCAACG \\
& CD147-R & TTCCGGCGCTTCTCGTAGA \\
GAPDH & GAPDH-F & AAGGTGAAGGTCGGAGTCAAC \\
& GAPDH-R & GGGGTCATTGATGGCAACAATA \\
\hline
\end{tabular}

In the table, the letters $\mathrm{F}$ and $\mathrm{R}$ stand for forward and reverse, respectively.

compared to the control group (DMSO group) $(P<0.01)$ (Figure 1(b)).

3.2. ANDR Blocked the GC Cell Cycle. To explore the effect of ANDR on the cell cycle of gastric cancer cells, we examined the cell cycle of SGC 7901 after treatment with different concentrations of ANDR using flow cytometry. SGC7901 cells were incubated with the following concentrations of ANDR for $48 \mathrm{~h}: 0 \mu \mathrm{g} / \mathrm{ml}$ (N, DMSO group), $40 \mu \mathrm{g} / \mathrm{ml}(\mathrm{H}), 20 \mu \mathrm{g} / \mathrm{ml}$ $(\mathrm{M})$, and $5 \mu \mathrm{g} / \mathrm{ml}(\mathrm{L})$. Then, analysis of the cell cycle in all groups was performed. As shown in Figure 2, both the highdose and middle-dose groups of ANDR caused SGC7901 cell cycle arrest at G2/M phase. Meanwhile, the low-dose group and the control group showed $59.01 \%$ and $52.32 \%$ of SGC 7901 cells in G1 phase, respectively, and increasing concentrations of ANDR decreased the proportion of GC cells at G1 phase (M group $49.84 \%$ and $\mathrm{H}$ group $37.39 \%$ ). ANDR at $40 \mu \mathrm{g} / \mathrm{ml}$ and $20 \mu \mathrm{g} / \mathrm{ml}$ arrested the cells at G2/M phase, at $36.2 \%$ and $24.39 \%$, respectively. These data suggested that ANDR can block the cell cycle at the G2/M phase (Figure 2).

3.3. ANDR Induced Apoptosis in GC Cells. To confirm the induction of apoptosis by ANDR, media with high, middle, and low dosages of ANDR were used to incubate SGC7901 cells. After incubation for $48 \mathrm{~h}$, apoptosis was examined using flow cytometry with Annexin-V-FITC/PI staining. We found that the apoptosis ratios of the high group, middle group, and low group, were $28.4 \%, 19.9 \%$, and $16.5 \%$, respectively, and were all higher than the control groups $(12 \%)(P<0.01$, compared to group $\mathrm{M}$ and $\mathrm{H} ; P<0.05$, compared to group L) (Figure 3). The results suggested that ANDR could induce apoptosis of GC cells.

3.4. ANDR Decreased Migration Ability. To examine whether ADNR influences the migration of GC cells, we performed a wound healing assay. After incubation with ANDR for $24 \mathrm{~h}$, SGC 7901 were scratched and complete media without ANDR was added and the cells were cultured for $24 \mathrm{~h}$. Microscopy imaging of the cells showed greater speed and activity for 


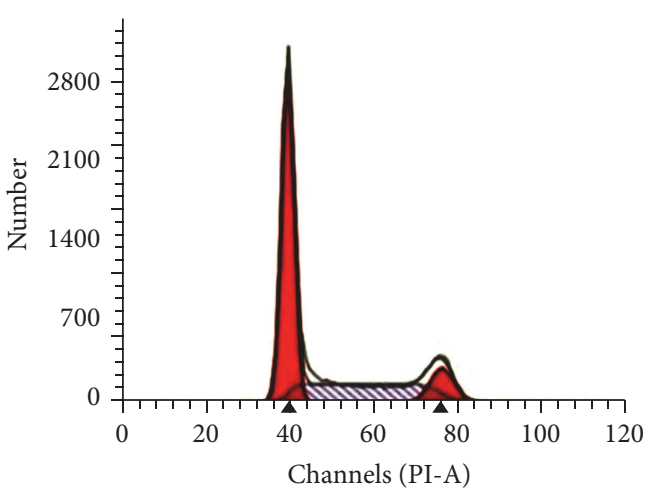

(a)

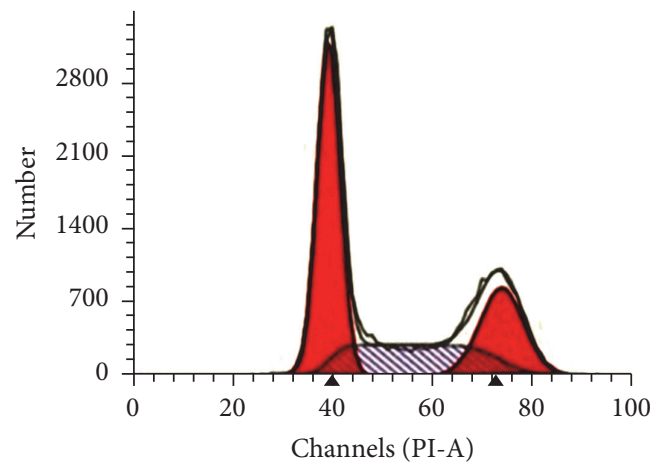

(c)

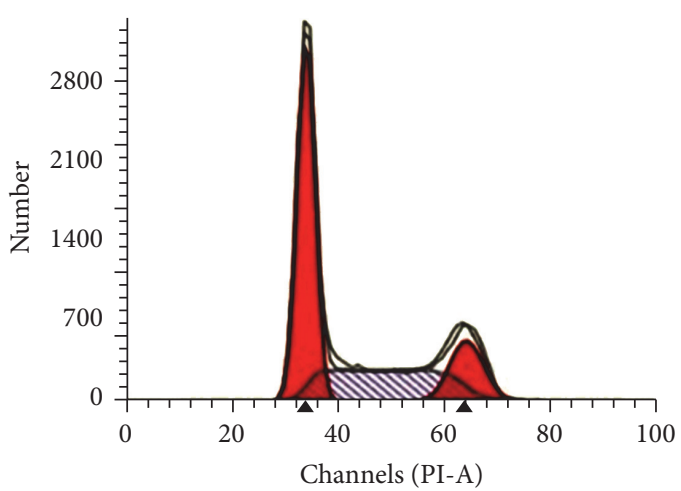

(b)

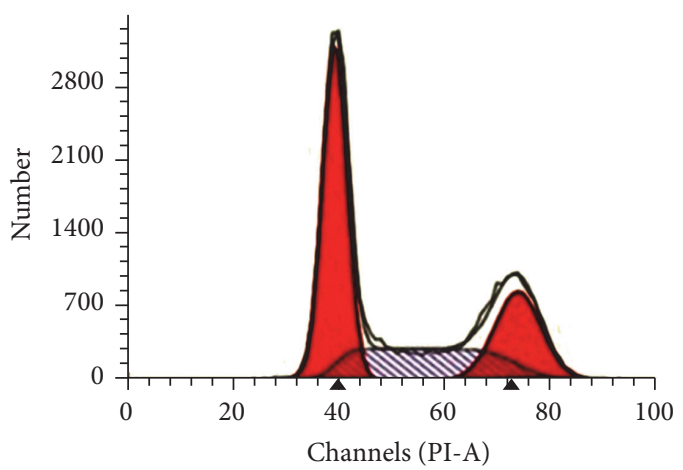

(d)

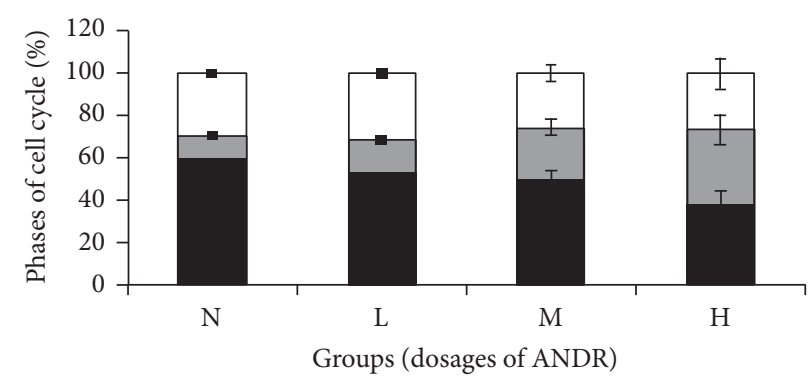

$\mathrm{G} 1$ $\mathrm{S}$

$\mathrm{G} 2 / \mathrm{M}$

(e)

FIGURE 2: Cell cycle of SGC 7901 cells affected by ANDR at different dosages. (a) Cell cycle of control group (N), (b) cell cycle of low dosage of ANDR group, (c) cell cycle of middle dosage of ANDR group, (d) cell cycle of high dosage of ANDR group, and (e) statistical values of groups at different cell phases. Groups $\mathrm{M}$ and $\mathrm{H}$ had significantly higher percentages of cells at $\mathrm{G} 2 / \mathrm{M}$ phases than groups $\mathrm{N}$ and $\mathrm{L}(P<0.01$, Student's $t$-test).

the cells in the control group compared to the ANDR-treated cells (Figure 4). In addition, increasing ANDR concentrations further decreased the cell migration activity.

3.5. ANDR Inhibited GC Cell Invasion. First, SGC 7901 cells were treated by ANDR with different dosages for $24 \mathrm{~h}$. Then, ANDR-treated SGC 7901 cells were detached and plated in transwell dishes for $48 \mathrm{~h}$. After that, the cells were fixed, stained, and imaged. As shown in Figure 5, ANDR decreased the invasion ability of the GC cells in a dose-dependent manner. A reduced number of invasive cells were observed with the high, middle, and low dose groups compared to the control group.

3.6. ANDR Reduced MMP-2 and MMP-9 Activities. Gelatin can be digested by MMP proteins, and decreasing MMP capacity is one of the goals to reduce the incidence of metastasis [16]. Thus, we used a gelatin-containing gel to examine MMP-2 and MMP-9 activities. We found that ANDR affected MMP-2 and MMP-9 activity, compared to the control group. However, no marked difference was found between the different concentrations of ANDR (Figure 6). 


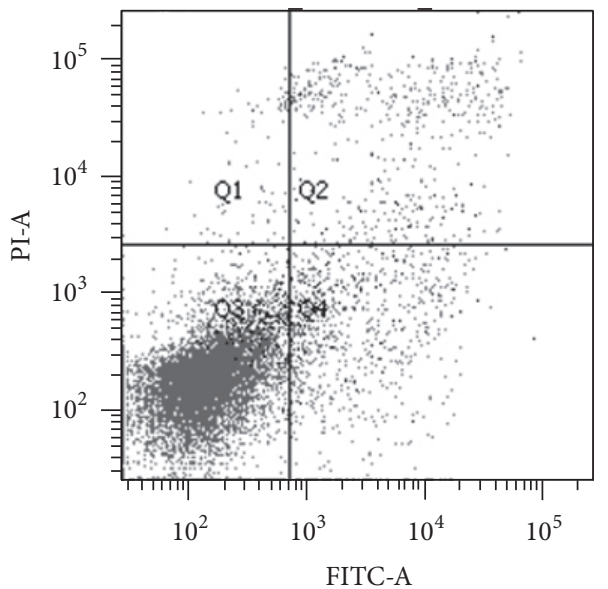

(a)

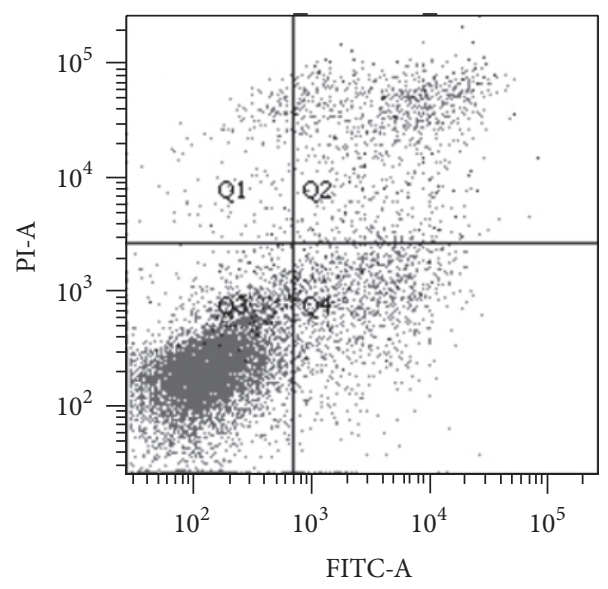

(c)

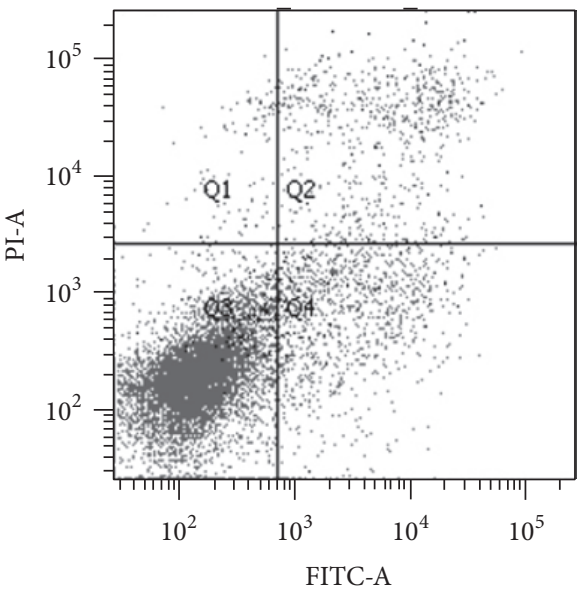

(b)

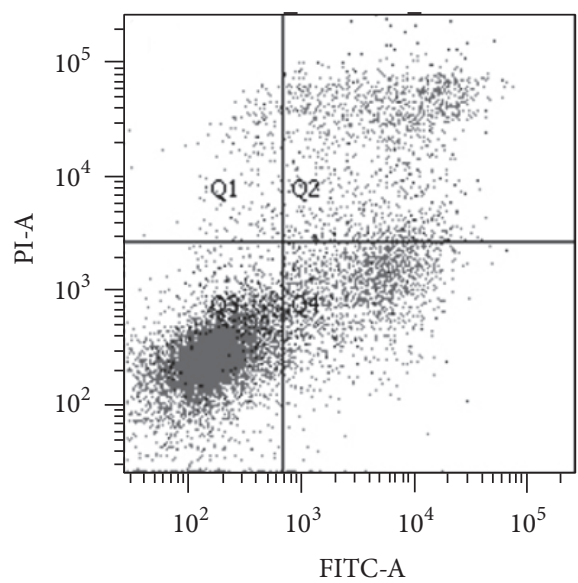

(d)

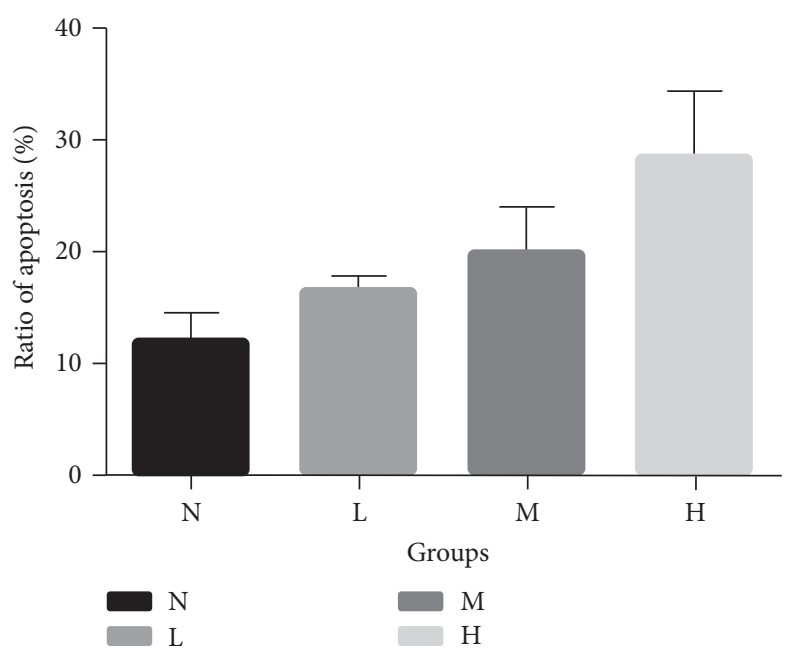

(e)

FIGURE 3: Effects of ANDR with different dosages on GC cell apoptosis. (a) Apoptosis of control group (N), (b) apoptosis of Low dosage of ANDR group, (c) apoptosis of middle dosage of ANDR group, (d) apoptosis of high dosage of ANDR group, and (e) statistical values of apoptosis ratio in different groups. Groups L, M, and $\mathrm{H}$ had significantly higher ratio of apoptotic cells than group $\mathrm{N}(P<0.05$ compared to group L, $P<0.01$ compared to group $\mathrm{H}$ and $\mathrm{M}$, using Student's $t$-test). 

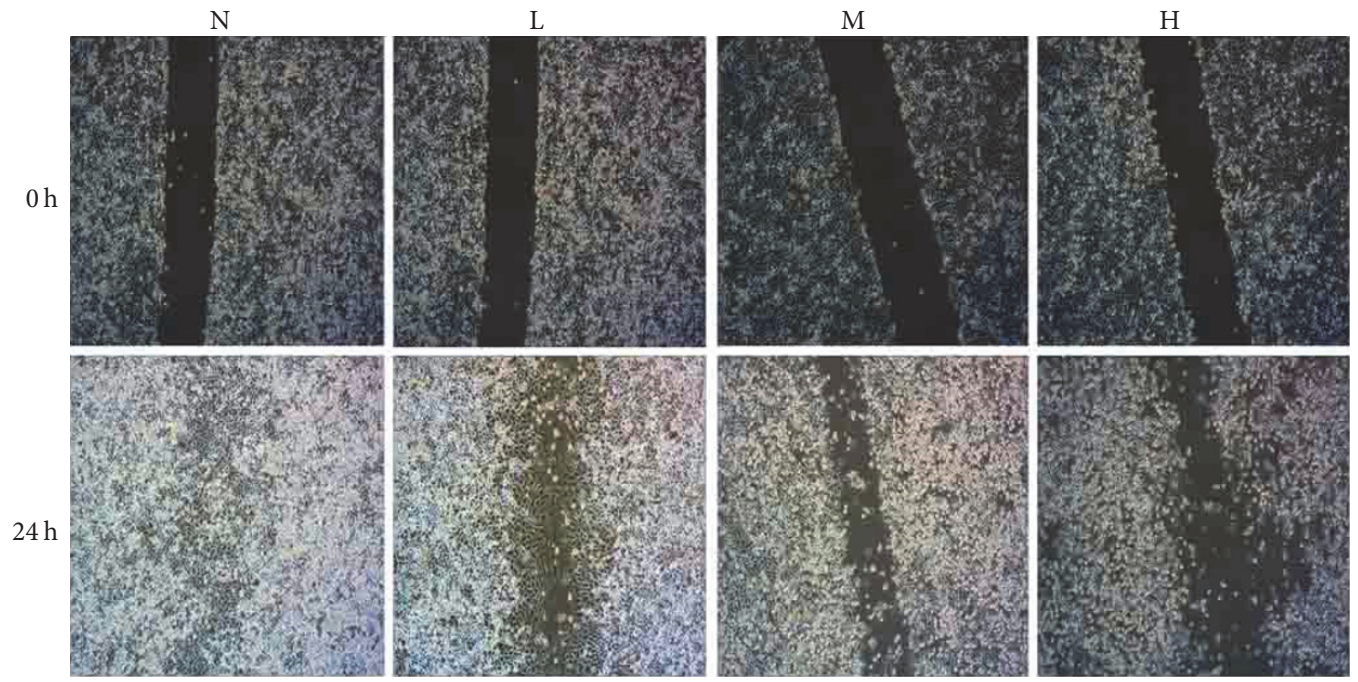

FIGURE 4: Wound healing of GC cells with ANDR. After incubating with ANDR, GC cells were scratched with pipette tips. After 24 h, cells of the control group had higher migration activity than groups treated by ANDR. In the figure, $\mathrm{N}$ denotes control group, $\mathrm{H}$ denotes high dosage of ANDR, M denotes middle dosage of ANDR, and L denotes low dosage of ANDR.

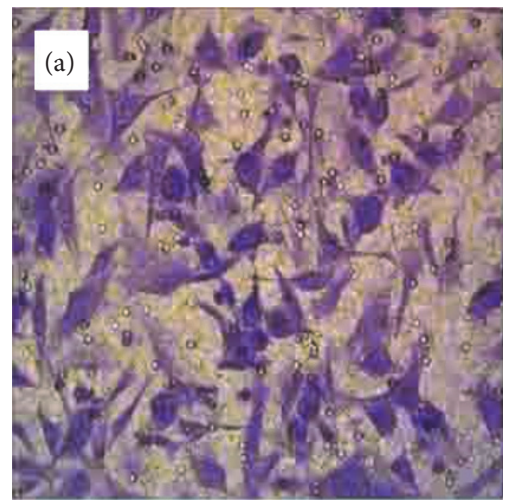

(a)

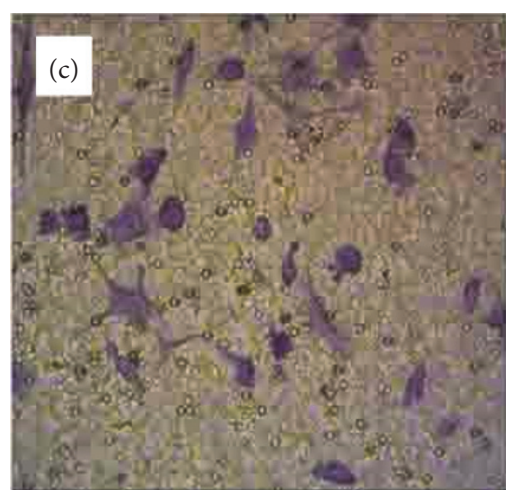

(c)

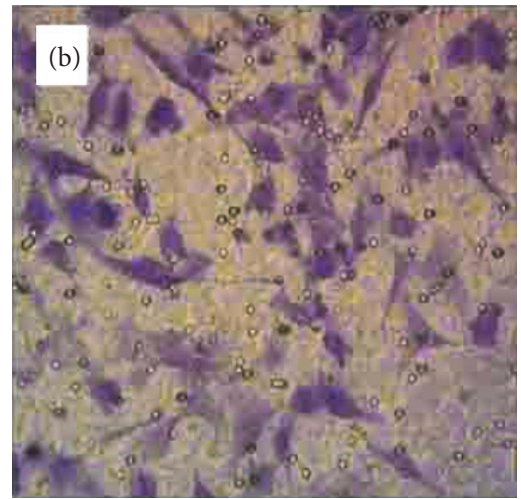

(b)

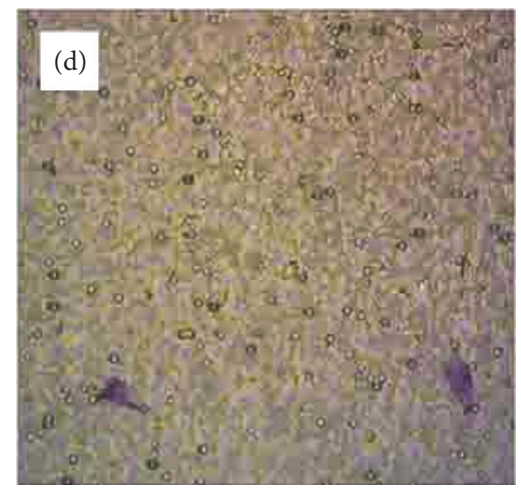

(d)

FIGURE 5: Transwell assay of GC cells treated by ANDR. After incubating with ANDR for $24 \mathrm{~h}$, SGC 7901 cells were seeded into transwell dishes for the invasion assay. As the concentration of ANDR increased, the numbers of transferred cells decreased. (a) Control group, (b) low-dose group, (c) middle-dose group, and (d) high-dose group. 


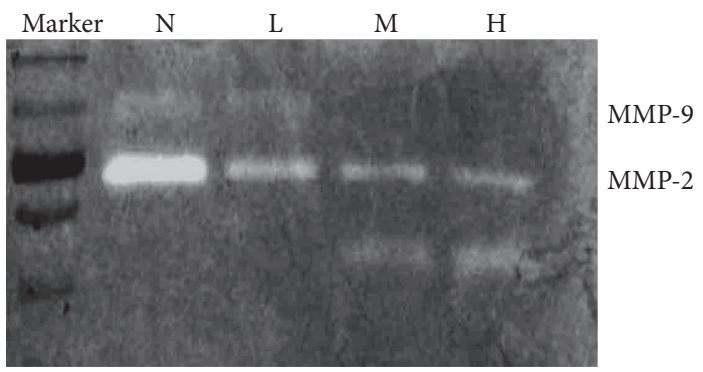

FIGURE 6: Gelatin-zymography analysis of protease activity of MMP-9 and MMP-2. Gel containing gelatin was used to assess the protease activity of MMP-9 and MMP-2. MMP-9 and MMP-2 activity was decreased as the concentration of ANDR increased. Marker denotes protein marker. In the figure, $\mathrm{N}$ denotes control group, $\mathrm{H}$ denotes high dosage of ANDR, $\mathrm{M}$ denotes middle dosage of ANDR, and L denotes low dosage of ANDR.

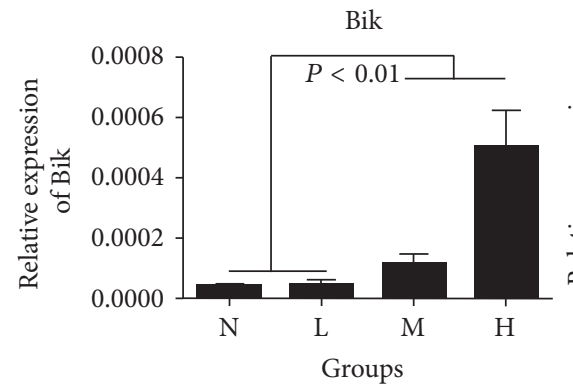

Survivin

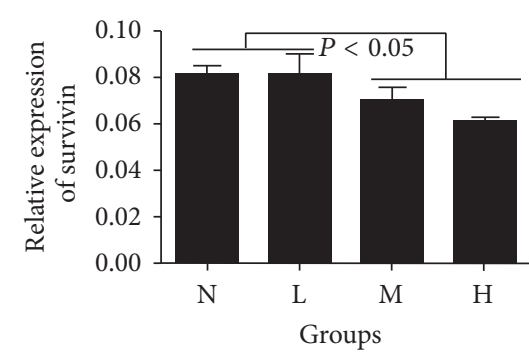

MMP-2

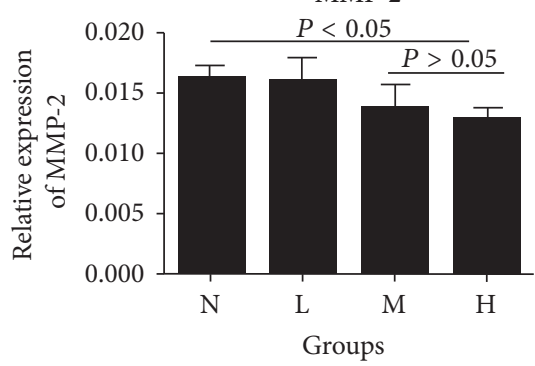

$\operatorname{Bax}$

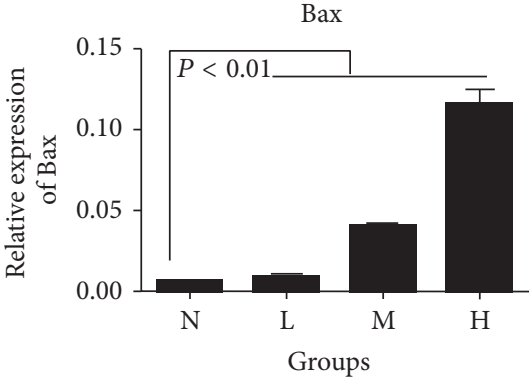

TIMP-1

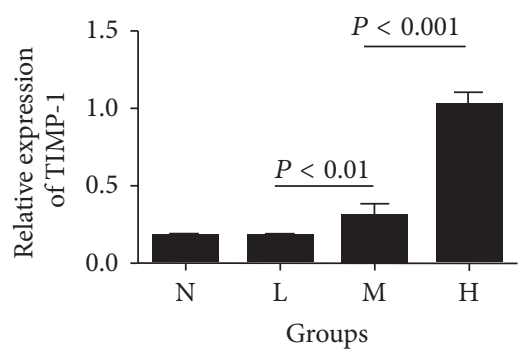

MMP-9

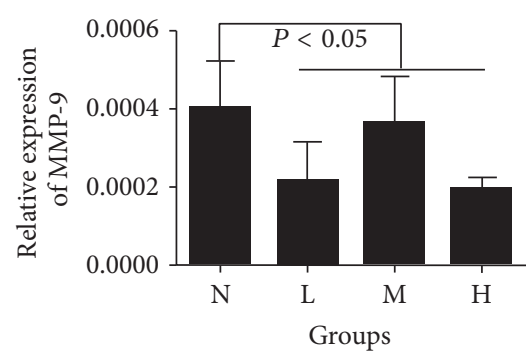

$\mathrm{Bcl}-2$

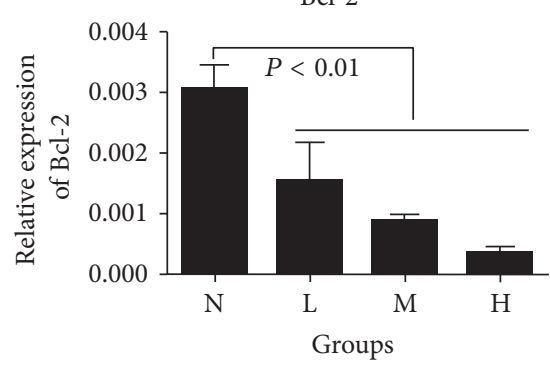

TIMP-2

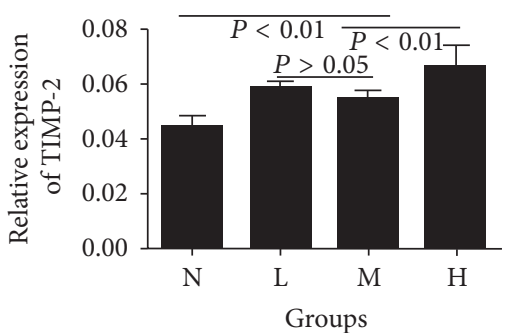

$\mathrm{CD} 147$

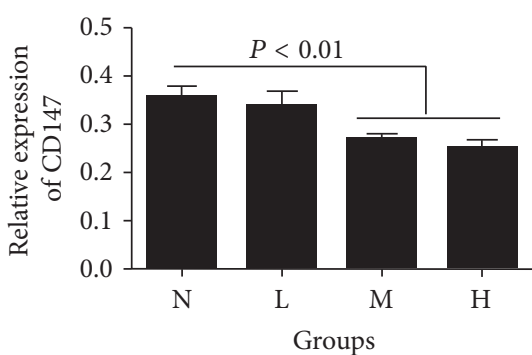

FIGURE 7: Relative expression of genes associated with invasion and apoptosis of cancer cells. ANDR could have an impact on the expression of genes involved in apoptosis, invasion, and survival. Bik, Bax, and Bcl-2 have roles in apoptosis. Proapoptosis genes, Bik and Bax, were upregulated and antiapoptosis gene, Bcl-2, was downregulated after stimulation by ANDR. Meanwhile, survivin, a gene for sustaining cell survival, was also downregulated after ANDR treatment. TIMP-1, TIMP-2, MMP-2, MMP-9, and CD147 are a cluster of genes involved in cellular invasion, including degradation of extracellular matrix components, digestion of basement membrane, and sustaining cell survival. TIMP-1/2 was significantly upregulated while MMP-2/9 and CD147 was downregulated in GC cells after incubation with ANDR for 48 h. 


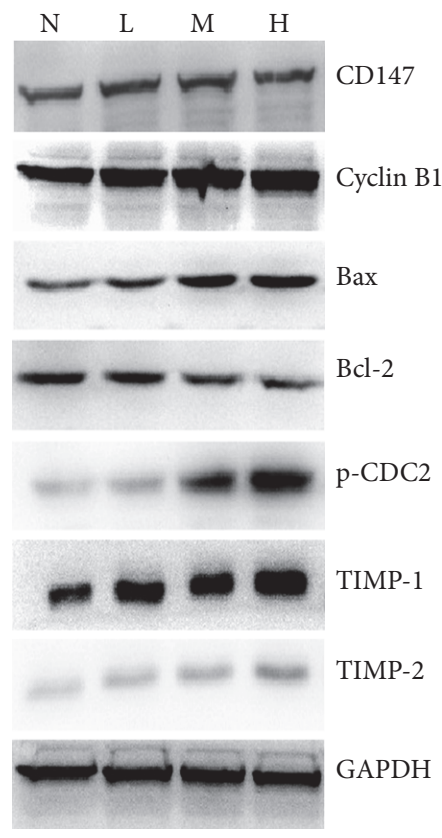

FIGURE 8: Immunoblots for levels of proteins associated with invasion and apoptosis of cancer cells. GC cells were incubated with ANDR for 48-72 h and cell lysates were collected for western blotting. Apoptosis genes (Bax and Bcl-2), cell cycle genes (cyclin B1 and CDC2), and invasion genes (TIMP-1/2 and CD147) had altered expression levels induced by ANDR at different concentration.

The data showed that ANDR could reduce protease activity of MMP-9 and MMP-2 secreted from SGC 7901 cells in culture.

3.7. ANDR Changed MMP-2, MMP-9, TIMP-1, TIMP2, CD147, Bax, Bik, and Survivin Expression. To explore the potential mechanisms behind the effects of ANDR on GC cells, we performed real-time PCR for the detection of genes involved in apoptosis and invasion of cancer cells. After $48 \mathrm{~h}$ of incubation of ANDR and GC cells, real-time PCR was employed to examine the expression of genes with roles in cell invasion (TIMP-1, TIMP-2, MMP-2, MMP-9, and CD147) and in apoptosis and survival (Bcl-2, Bax, Bik, and survivin). TIMP-1/2, Bax, and Bik were upregulated in GC cells, whereas MMP-2, MMP-9, CD147, Bcl-2, and survivin were downregulated. These results indicated that ANDR has the capacity to inhibit invasion and to induce apoptosis (Figure 7).

3.8. ANDR Altered Levels of Proteins Related to Metastasis, the Cell Cycle, and Apoptosis. At the mRNA level, we investigated the expression of genes involved in cell invasion, apoptosis, and survival. Next, we examined the protein levels of the same genes. Proteins involved in cancer cell invasion, including TIMP-1, TIMP-2, and CD147, were expressed at increased levels after ANDR treatment (Figure 8). Meanwhile, ANDR could upregulate apoptosis-promoting Bax and downregulate apoptosis-preventing protein $\mathrm{Bcl}-2$ (Figure 8). Additionally, the levels of cell cycle-inhibiting proteins, cyclin B1 and CDC2, were enhanced by with increased concentrations of ANDR (Figure 8). These data suggested that ANDR could suppress proliferation, promote apoptosis, and inhibit invasion by modulating the expression of proteins including cyclin B1, phosphorylated CDC2, TIMP-1, TIMP-2, CD147, and Bcl-2 and Bax.

\section{Discussion}

The high invasion capacity of cancer cells is one of the major reasons for the poor diagnosis of cancer patients. Gastric cancer is a common gastroenterological malignancy, and increasing evidence shows that the invasion and metastasis of this cancer occur in multiple steps and are due to multiple genes with complicated processes. Thus, determining the molecular mechanisms and molecules involved is important for developing highly efficient anticancer drugs. Within this context, an increasing number of herbal drugs are displaying promising effects; andrographolide is one such herb.

In the present work, we found that andrographolide could inhibit the proliferation, invasion, and metastasis of gastric cancer by inhibiting MMP protein activity and upregulating TIMP proteins. Additionally, the expression of apoptosisassociated proteins, such as Bcl-2 and Bax, and some oncogenes, such as survivin, were altered after andrographolide treatment.

Gelatin zymography is used to detect the activity of MMP family proteins. In this study, SGC7901 cells incubated with andrographolide showed decreasing MMP-2 and MMP-9 activities compared with control cells. In addition, the metastasis-associated genes TIMP-1 and TIMP-2 were upregulated by ANDR, whereas CD147 was not.

Inhibiting cancer cell proliferation may be achieved by blocking the cell cycle and preventing invasion and metastasis can be accomplished by altering MMP and TIMP proteins. The degradation of stromal and basal tissues during the migration of cancer cells is a key event for invasion and metastasis. In particular, collagen in the extracellular space may be insensitive to proteases but sensitive to MMPs [17]. To date, there are 28 MMP family members described, including the collagenase subfamily (MMP-1, MMP-8, and MMP-13), the gelatinase subfamily (MMP-2 and MMP-9), the stromelysin subfamily (MMP-3, MMP-10, and MMP11), membrane-associated MMPs (MMP-14, MMP-15, MMP16, MMP-17, MMP-23, MMP-24, and MMP-25), and other MMPs, all of which possess a $\mathrm{Zn}$ ion-dependent endopeptidase activity homologue domain [18-20].

MMPs have unique roles in tumor progression, invasion, and metastasis. Normally, TIMPs (tissue inhibitors of metalloproteases) act as inhibitors of MMP family proteins, of which there are four members: TIMP-1, TIMP-2, TIMP-3, and TIMP-4. The N-terminus (125 residues) and C-terminus (65 residues) of TIMP contain 3 conserved S-S disulfide bonds [21, 22]. Upregulating TIMPs could restrain invasion and metastasis [23]. There are several steps involved in invasion, but detachment from the basal membrane and ECM degradation by MMPs are key [24]. There are reports that MMP-2 and MMP-9 can degrade ECM components to facilitate invasion [25]. 
TIMP-1 is an important endoinhibitor of MMP-9, whereas TIMP-2 inhibits MMP-2. TIMP proteins can noncovalently bind to MMP proteins at a ratio of $1: 1$ to inhibit MMP activity in cell invasion and metastasis.

CD147 is a member of an immunoglobulin protein superfamily and is expressed by hematopoietic stem cells and blood cells. The function of the protein is to stimulate fibroblasts and tumor cells to secrete MMPs. Thus, CD147 is an activator of MMPs [26].

\section{Conclusions}

ANDR has antigastric cancer effects in vitro. ANDR may repress the proliferation and metastasis of GC cells by increasing TIMP protein expression and reducing the expression and activities of MMPs. Additionally, the Bcl-2 family may be involved. Further understanding of its anticancer mechanism may result in the broad clinical application of ANDR.

\section{Competing Interests}

The authors all declare that there is no conflict of interests regarding the publication of this paper.

\section{Authors' Contributions}

Wensheng Pan designed the work, Lei Dai and Gang Wang conducted the experiments. Wensheng Pan, Lei Dai, and Gang Wang analyzed the data and wrote the manuscript. Lei Dai and Gang Wang contributed equally to this work.

\section{Acknowledgments}

This work is supported in part by National Natural Science Foundation of China (no. 81372302), Zhejiang Province Natural Science Foundation of China (nos. LY12H16016 and LY16H160057), Health and Family Planning Commission of Zhejiang Province (no. 2015114271), and Science and Technology Department of Zhejiang Province (no. 2015F10034).

\section{References}

[1] A. Jemal, F. Bray, M. M. Center, J. Ferlay, E. Ward, and D. Forman, "Global cancer statistics," CA: A Cancer Journal for Clinicians, vol. 61, no. 2, pp. 69-90, 2011.

[2] Z.-D. Wang, C. Huang, Z.-F. Li et al., "Chrysanthemum indicum ethanolic extract inhibits invasion of hepatocellular carcinoma via regulation of MMP/TIMP balance as therapeutic target," Oncology Reports, vol. 23, no. 2, pp. 413-421, 2010.

[3] W.-H. Peng, Y.-C. Tien, C.-Y. Huang et al., "Fraxinus rhynchophylla ethanol extract attenuates carbon tetrachlorideinduced liver fibrosis in rats via down-regulating the expressions of uPA, MMP-2, MMP-9 and TIMP-1," Journal of Ethnopharmacology, vol. 127, no. 3, pp. 606-613, 2010.

[4] R. Jotwani, S. V. K. Eswaran, S. Moonga, and C. W. Cutler, "MMP-9/TIMP-1 imbalance induced in human dendritic cells by Porphyromonas gingivalis," FEMS Immunology and Medical Microbiology, vol. 58, no. 3, pp. 314-321, 2010.
[5] X. Zhu and J. Li, "Gastric carcinoma in China: current status and future perspectives (review)," Oncology Letters, vol. 1, no. 3, pp. 407-412, 2010.

[6] A. M. Marcaccini, C. A. Meschiari, L. R. Zuardi et al., "Gingival crevicular fluid levels of MMP-8, MMP-9, TIMP-2, and MPO decrease after periodontal therapy," Journal of Clinical Periodontology, vol. 37, no. 2, pp. 180-190, 2010.

[7] J. Rysz, M. Banach, R. A. Stolarek et al., "Serum metalloproteinases MMP-2, MMP-9 and metalloproteinase tissue inhibitors TIMP-1 and TIMP-2 in patients on hemodialysis," International Urology and Nephrology, vol. 43, no. 2, pp. 491498, 2011.

[8] L. Zhang, X.-H. Hao, X.-H. Wang, F. Yang, Z.-Y. Guo, and X. Pei, "Effect of $\mathrm{SiO} 2$ on expression of MMP-9/TIMP-1 in human alveolar macrophages in vitro," Chinese Journal of Industrial Hygiene and Occupational Diseases, vol. 27, no. 6, pp. 341-344, 2009.

[9] X.-X. Wang, Y.-C. Li, X.-P. Ma, and Z.-C. Han, "Effects of electroacupuncture at Jiaji (EX-B 2) on extracellular matrix MMP-1, MMP-3 and TIMP-1 levels in the degenerated cervical intervertebral disc in rats," Acupuncture Research, vol. 34, no. 4, pp. 248-251, 2009.

[10] Y.-D. Wang, X.-Y. Tan, and K. Zhang, "Correlation of plasma MMP-1 and TIMP-1 levels and the colonic mucosa expressions in patients with ulcerative colitis," Mediators of Inflammation, vol. 2009, Article ID 275072, 5 pages, 2009.

[11] A. Varma, H. Padh, and N. Shrivastava, "Andrographolide: a new plant-derived antineoplastic entity on horizon," EvidenceBased Complementary and Alternative Medicine, vol. 2011, Article ID 815390, 9 pages, 2011.

[12] K. Hamzaoui, B. Maître, and A. Hamzaoui, "Elevated levels of MMP-9 and TIMP-1 in the cerebrospinal fluid of neuro-Behçet's disease," Clinical and Experimental Rheumatology, vol. 27, no. 2, S53, pp. S52-S57, 2009.

[13] J. Marshall, "Transwell ${ }^{5}$ invasion assays," Methods in Molecular Biology, vol. 769, pp. 97-110, 2011.

[14] W.-S. Wu, R. K. Tsai, C. H. Chang, S. Wang, J.-R. Wu, and Y.-X. Chang, "Reactive oxygen species mediated sustained activation of protein kinase $\mathrm{C} \alpha$ and extracellular signal-regulated kinase for migration of human hepatoma cell Hepg2," Molecular Cancer Research, vol. 4, no. 10, pp. 747-758, 2006.

[15] H. Frankowski, Y.-H. Gu, J. H. Heo, R. Milner, and G. J. Del Zoppo, "Use of gel zymography to examine matrix metalloproteinase (gelatinase) expression in brain tissue or in primary glial cultures," Methods in Molecular Biology, vol. 814, pp. 221-233, 2012.

[16] M. Toth, A. Sohail, and R. Fridman, "Assessment of gelatinases (MMP-2 and MMP-9) by gelatin zymography," Methods in Molecular Biology, vol. 878, pp. 121-135, 2012.

[17] K.-H. Hung, H.-W. Hung, H.-B. Yang, C.-C. Lu, J.-J. Wu, and B.-S. Sheu, "Host single nucleotide polymorphisms of MMP$9-1562 /$ TIMP-1 372 have gender differences in the risk of gastric intestinal metaplasia after Helicobacter pylori infection," Helicobacter, vol. 14, no. 6, pp. 580-587, 2009.

[18] W. J. Piotrowski, A. Nawrocka-Kunecka, A. Antczak et al., "Metalloproteinases MMP-9, MMP-2 and their tissue inhibitors TIMP-1, TIMP-2 in peripheral transbronchial lung biopsies of patients with sarcoidosis," Polskie Archiwum Medycyny Wewnetrznej, vol. 119, no. 10, pp. 628-635, 2009.

[19] A. Yildirim, O. V. Ozkan, A. Aslan, Z. Koseoglu, and A. Borazan, "The effects of low-dose erythropoiesis-stimulating 
agents on peritoneal fibrosis induced by chemical peritonitis and on peritoneal tissue MMP2 and TIMP2 levels in rats," Renal Failure, vol. 31, no. 7, pp. 567-572, 2009.

[20] M.-H. Lee, S. Atkinson, M. Rapti et al., "The activity of a designer tissue inhibitor of metalloproteinases (TIMP)-1 against native membrane type 1 matrix metalloproteinase (MT1MMP) in a cell-based environment," Cancer Letters, vol. 290, no. 1, pp. 114-122, 2010.

[21] X. Zhang, Y. Wang, G. Yamamoto, and T. Tachikawa, "Expression of matrix metalloproteinases MMP-2, MMP-9 and their tissue inhibitors TIMP-1 and TIMP-2 in the epithelium and stroma of salivary gland pleomorphic adenomas," Histopathology, vol. 55, no. 3, pp. 250-260, 2009.

[22] F. Karayel, I. Pakiş, A. Akçay Turan, B. Öz, and S. Çellik, "Assessment of smoking related pathologic changes and MMP9, TIMP-1 expressions of the lung," Tuberkuloz ve Toraks, vol. 57, no. 2, pp. 129-135, 2009.

[23] L. F. Raheja, D. C. Genetos, and C. E. Yellowley, "The effect of oxygen tension on the long-term osteogenic differentiation and MMP/TIMP expression of human mesenchymal stem cells," Cells Tissues Organs, vol. 191, no. 3, pp. 175-184, 2010.

[24] B. Bıyıkoğlu, N. Buduneli, L. Kardeşler, K. Aksu, M. Pitkala, and T. Sorsa, "Gingival crevicular fluid MMP-8 and -13 and TIMP-1 levels in patients with rheumatoid arthritis and inflammatory periodontal diseas," Journal of Periodontology, vol. 80, no. 8, pp. 1307-1314, 2009.

[25] L. Mäkitalo, T. Sipponen, P. Kärkkäinen, K.-L. Kolho, and U. Saarialho-Kere, "Changes in matrix metalloproteinase (MMP) and tissue inhibitors of metalloproteinases (TIMP) expression profile in Crohn's disease after immunosuppressive treatment correlate with histological score and calprotectin values," International Journal of Colorectal Disease, vol. 24, no. 10, pp. 11571167, 2009.

[26] C. A. London, H. S. Sekhon, V. Arora, D. A. Stein, P. L. Iversen, and G. R. Devi, "A novel antisense inhibitor of MMP9 attenuates angiogenesis, human prostate cancer cell invasion and tumorigenicity," Cancer Gene Therapy, vol. 10, no. 11, pp. 823-832, 2003. 


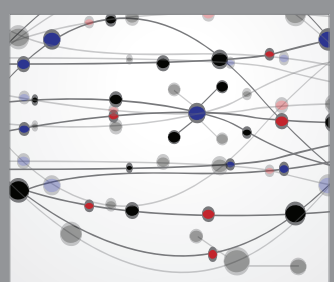

The Scientific World Journal
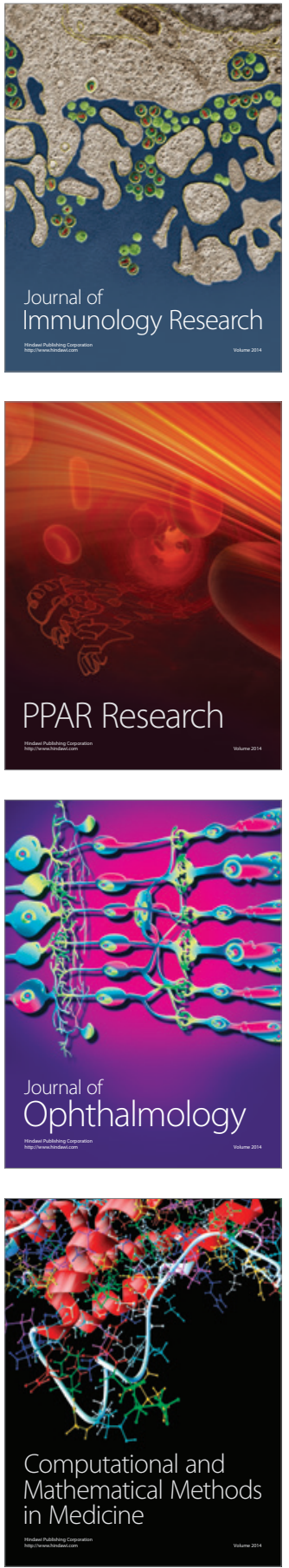

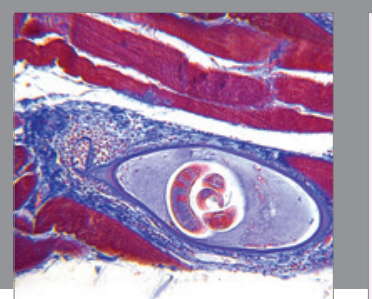

Gastroenterology Research and Practice
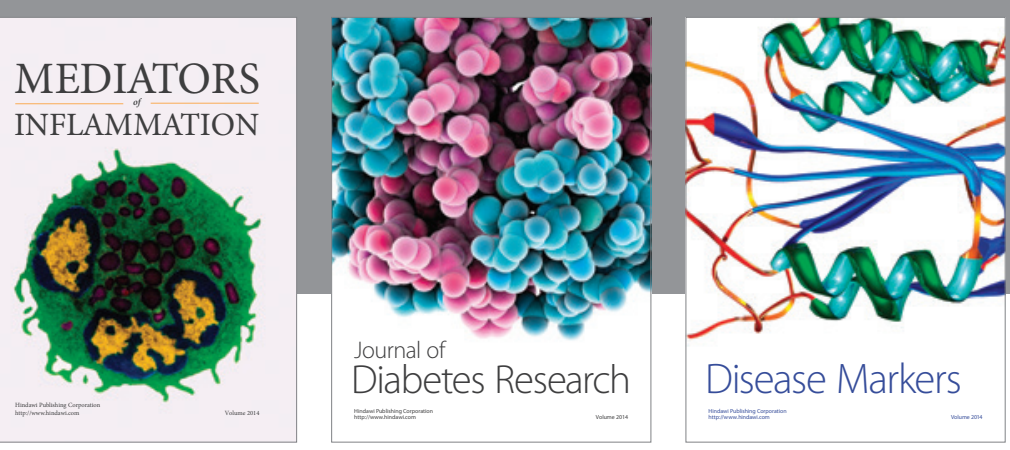

Disease Markers

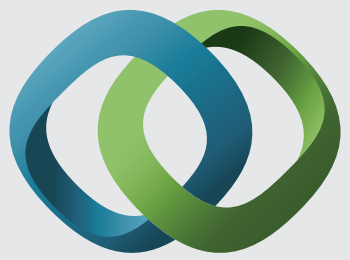

\section{Hindawi}

Submit your manuscripts at

https://www.hindawi.com
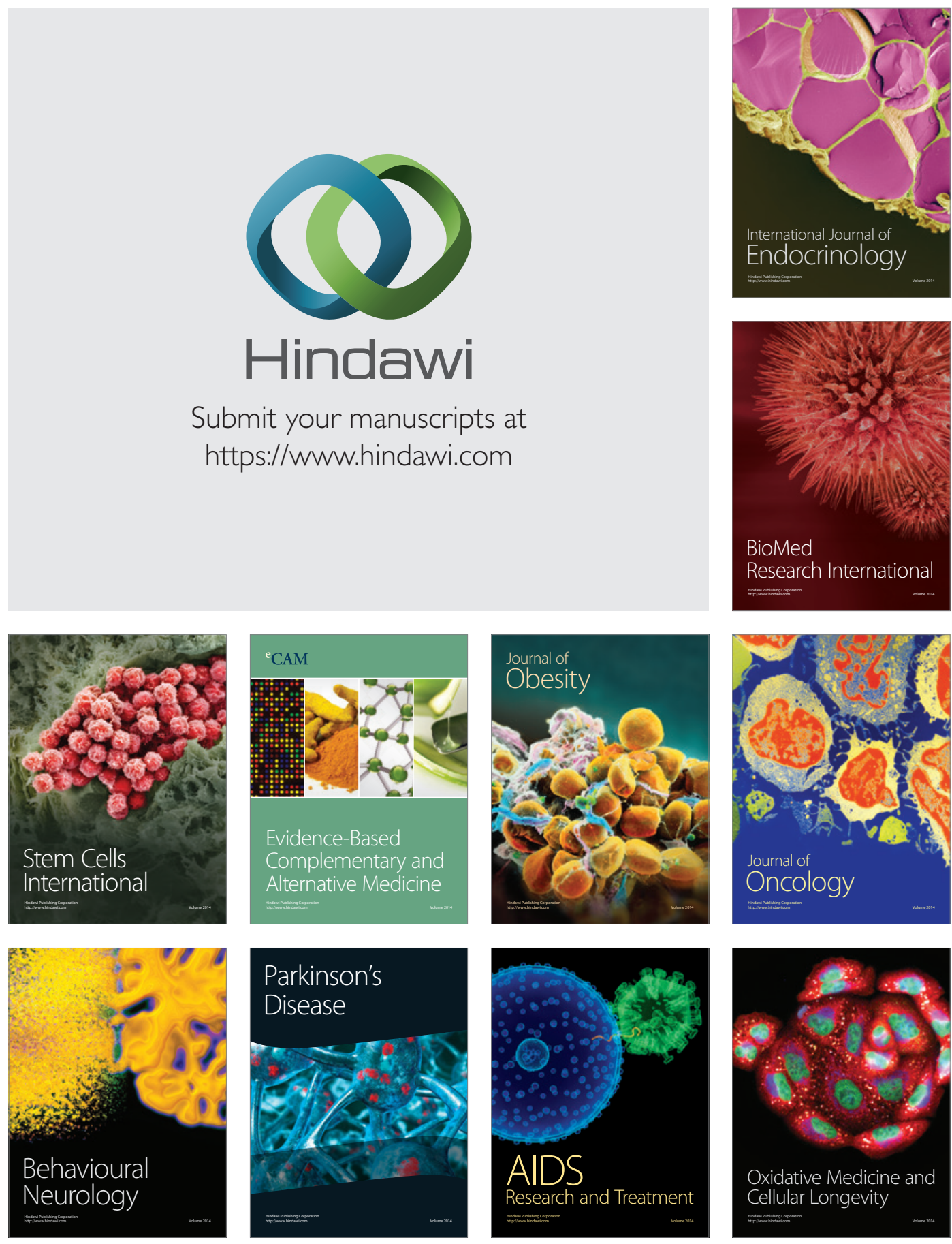